\title{
The new Hamas document: An analytical reading of its development and application
}

\author{
Dokumen Hamas baru: Interpretasi analitik tentang \\ perkembangan dan aplikasi
}

\author{
Ahmed ALMadani \\ Doctorate Student of Social Science, Faculty of Social and Political Science, \\ Universitas Airlangga \\ Kampus B Dharmawangsa Dalam, Surabaya, Jawa Timur 60286 \\ E-mail: palmaster007@hotmail.com
}

\begin{abstract}
The Palestine Liberation Organization (PLO) has been the sole legitimate representative of the Palestinian people since the creation of the Palestinian. The PLO adopted the option of armed struggle against the Israeli occupation, but ended with the signing of the Oslo accords between the Palestine Liberation Organization and Israel in the 1990s. The Islamic Resistance Movement in Palestine (Hamas) was established in the 1980s. Hamas developed its political ideas through a new political document resulted in a new vision to resolve the Palestinian-Israeli conflict by transforming the conflict from religious conflict to political conflict and accepting the establishment of a Palestinian state on the 1967 borders as a common ground between the Palestinian movements and parties, while the armed struggle remains a path of resistance. The purpose of this article is to truly understand this development and the possibility of its application on the ground or not, by clarifying the differences between the ideas of the former and the new Hamas, The researcher relied on a number of academic articles and political research in addition to the political TV shows that talked about the new document, the Arab and international positions of this document, The result of this article is that the Palestinian Hamas movement as a Palestinian resistance movement is capable of political development and finding the alternatives available to solve the Palestinian file while preserving the Palestinian national constants. The Conclusion is the Palestinian Hamas movement is developing with the developments of regional and international events and political development has been partially accepted internationally, Hamas have to work more in the political field to balance between political development and the Palestinian constants.
\end{abstract}

Keywords: Hamas, PLO, Hamas new document, Palestine-Israel conflict

\section{Abstrak}

Organisasi Pembebasan Palestina (The Palestine Liberation Organization/PLO) adalah perwakilan tunggal sah rakyat Palestina. PLO melakukan upaya perlawanan bersenjata untuk melawan pendudukan Israel di Palestina dan berujung pada penandatanganan perjanjian Oslo antara PLO dengan Israel di tahun 1990an. Gerakan pertahanan Islam Palestina (Hamas) didirikan pada tahun 1980-an, Hamas membangun ide politiknya melalui dokumen politik baru dengan visi untuk menyelesaikan konflik Palestina-Israel dengan merubah paradigma konflik ini dari semula sebagai konflik agama menjadi konflik politik. Selain itu, gerakan ini juga memperjuangkan batas-batas negara Palestina yang dibentuk pada tahun 1967 sebagai landasan gerakan. Selain itu, gerakan bersenjata juga tetap menjadi bagian dari perjuangan Hamas. Artikel ini membahas mengenai perkembangan politik Hamas dan apakah Hamas mengikuti gerakan yang telah ditempuh oleh PLO. Artikel ini bertujuan untuk mengungkap perbedaan ide yang diusung Hamas lama dan Hamas baru. Penelitian didasarkan pada sejumlah artikel ilmiah, riset politik, dan tayangan media TV mengenai dokumen terkait, serta posisi Arab dan dunia internasional mengenai dokumen Hamas. Temuan dari penelitian ini adalah bahwa gerakan Hamas di Palestina telah mampu menemukan alternatif untuk memecahkan konflik di Palestina dan disaat yang bersamaan, menjaga kepentingan nasional Palestina. Artikel ini menyimpulkan bahwa Hamas berkembang sesuai dengan perkembangan nasional dan internasional, meskipun gerakan politiknya hanya diterima oleh dunia internasional secara parsial. Oleh karena itu, Hamas perlu melakukan upaya lebih untuk menyeimbangkan perkembangan politiknya dengan kepentingan Palestina.

Kata kunci: Hamas, PLO, dokumen baru Hamas, konflik Israel-Palestina 


\section{Introduction}

The struggle with the State of Israel began in the 1940s. This conflict was based on the principle that the land of Palestine is Arab land but in other hand the Jews believe that they must establish their own state, the State of Israel, on the basis of their religious predictions (Lومحلإ, 2015).

With the development of political ideas and the field of international relations, there has been a political maturity for the Arabs, especially the Palestinians, that this conflict is a political conflict, not a religious one, and that the State of Israel is an alienated entity to the land of Palestine. With this maturity, the Palestinian national liberation movements led by Yasser Arafat began to adopt all kinds of resistance, including the armed resistance (ثاثب, 2004).

The Palestine Liberation Organization (PLO) was established in 1964. The PLO was the sole and legitimate representative of the Palestinian people. Yasser Arafat was the PLO's leader for a long time. Yasser Arafat is considered a great national figure and international symbol. Even the sectors the opposition in the Palestinian people continuously respect Yasser Arafat (“" 2004).

With the rise of the resistance movements in Palestine, the resistance movements of Islamic nature emerged within the Palestinian homeland, including the Islamic Jihad and Hamas. The Hamas movement was founded in 1987 and its principles and constitution are based on Islamic references and literature. Hamas is considered as a branch of the movement of the Muslim Brotherhood. Hamas is a movement with Sunni nature which resists the State of Israel in order to liberate Palestine ("لكرح حم

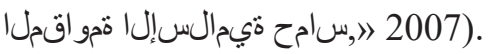

In this article, researcher will review the most important part of the Hamas Charter, which was based on 1987, the new Hamas document issued in May 2017, the differences between the Hamas Charter and the new document, as well as monitoring local, regional and international political positions towards the new Hamas document.

The most important thing in the Hamas charter issued in 1988 is that Hamas is a wing of the Muslim Brotherhood in Palestine. The movement of the Muslim Brotherhood is a global organization, which is the largest Islamic movement in the modern era. It is distinguished by the accurate perception and total comprehensiveness of all Islamic concepts in all spheres of life. Article 8 of the Charter states that Allah is its purpose, the Prophet is its leader, the Qur'an is its constitution, jihad (all kind of jihad, not just the military way) is its path, and dyeing to liberate the land of Palestine is the highest

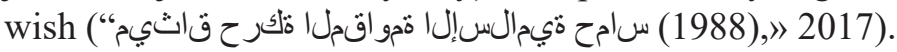

This is a noble goal sought by Hamas and the liberation of Palestine from those who took the land by force, using all types of struggle, whether political or military, as the seventh article states that the Islamic Resistance Movement is a ring of jihad in the face of the Zionist occupation, The martyr of Izz al-Din al-Qassam and his brothers the Mujahideen of the Muslim Brotherhood in 1936 goes to connect and link with another episode, including Jihad of the Palestinians and the efforts and jihad of the Muslim Brotherhood in the 1948 war, and the jihad operations of the Muslim Brotherhood in

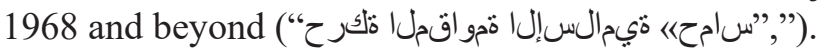

The relationship between the Hamas movement and the PLO has been the subject of debate and discussion, especially since Hamas is not part of the PLO because of the fundamental principles of the two sides. The parties tried to reach a compromise agreement that would satisfy all parties through elections for the Palestine Liberation Organization and the participation of Hamas in these elections, but so far has not been achieved due to internal and external reasons.

The charter of Hamas in 1988 is fundamentally opposed to the principles of the Palestine Liberation Organization (PLO), especially after the peace agreement between the Palestinians and Israelis in 1991, known as the Oslo agreement. The PLO adopted the option of peace as a strategic choice rather than a military option. 
The political dispute between the Palestine Liberation Organization (PLO) or which later became known as the Palestinian Authority (PA) and between the Hamas movement turned from a political ideological conflict into a military conflict between the two sides in the Gaza Strip in 2006-2007, resulting in the Hamas military takeover of the Gaza Strip. Israel launched three wars on the Gaza Strip, which led to the destruction of the entire infrastructure in the Gaza Strip. Thousands of martyrs and wounded and displaced in the Gaza Strip, all due to lack of consensus between the parties (the Palestinian Authority led by President Mahmoud Abbas and Hamas).

The disagreement between the Palestinian Authority and Hamas led to the division of the Palestinian people and the impact on the daily life of the Palestinians, especially in the Gaza Strip, in all areas of life and mainly the negative impact on the Palestinian social situation. The division has greatly exacerbated the situation in the occupied territories. The Hamas movement tried to develop its internal charter by adhering to the Palestinian national principles and trying to understand the current situation and to create a new document that carries with it what Hamas wants.

\section{Hamas document and social media}

Due to the sensitivity of the Palestinian Hamas movement, the impact of social networking sites on the decisions of the Palestinian Hamas movement is not good. This is due to the sensitivity of the people of the Palestinian Hamas movement, especially regarding the State of Israel and its ongoing attempt to destroy the Palestinian Hamas movement through assassinations and bombings of the leaders of the Palestinian Hamas movement. The view of people in social networking sites were noted after the announcement of the new document, which is as follows:

Firstly, there are parties who regarded the document as a natural progression of Hamas' political approach in its resistance against the Israeli occupation, and that the Palestinian Hamas movement aims to reconcile the constants of the Palestinian people with the new realities in the Middle East. Secondly, another party on the social networking sites expresses the other view that the new Hamas document is a concession to the Palestinian people's goals of establishing their independent state on all Palestinian soil (from the sea to the river). These people have compared the new Hamas document to the concessions made by Palestinian liberation until the concession reached recognition of the State of Israel during the Oslo agreement of the 1990s

\section{Hamas new document in 2017}

Many of the leaders of Hamas in Palestine and abroad emphasize that it is nothing more than a paper based on the legacy of the political movement without detracting from its fundamentals on the core issues of the conflict with Israel. The amendment came about three decades after the first charter of the movement under conditions of extreme accuracy and complexity, certainly, will include important issues that have been fixed in the literature of the movement, such as the issue of resistance. The concept of armed resistance to the Israeli occupation that the debate within Hamas may be greater on the issue of acceptance of a state within the 1967 with an impact on the exercise of the resistance and also the rest Land Phil Some say that Hamas accepted the 1967 borders as a state for the Palestinian people and stands but does not accept that this premise of accepting Hamas as a state on the 1967 borders was based on finding a common ground between Hamas and the PLO factions, including the

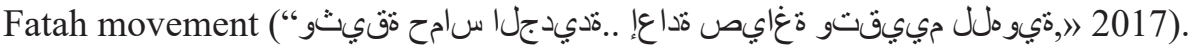

The movement of the Muslim Brotherhood was a major obstacle to Hamas, especially in its relationship with neighboring Egypt by the Hamas administration of the Gaza Strip. Furthermore, the relationship with western countries will not deviate much from all the political positions announced by the former and wants to combine these positions in New wording in a new paper. To those who want to know what Hamas wants, and although these amendments came to keep pace with radical changes on the global level and also to withdraw the pretexts from Israel and its supporters who are easy to incite 
to Hamas because of the terms of its first charter, those who adopt these amendments and their opponents within the movement do not guarantee to open. They have a new page of equal relations with Europe and the world and even with the countries of the region because of the experience of the PLO, which changed its charter during the time of the late President Yasser Arafat, which is one of several factors that may explain the difficulty and sensitivity of this new document or charter (2017).

Before going into the new Hamas document there is a series of events coinciding with the issuance of this document as an important events within Hamas, as follows: First, Yahya al-Sunwar was elected as head of Hamas in the Gaza Strip, replacing Ismail Haniyeh. Yahya Ibrahim Hassan al-Senwar was born in 1962 in the Khan Younis refugee camp in the Gaza Strip. He is originally from Majdal Ashkelon (inside Israel), but his family moved to Khan Yunis refugee camp during 1948 (the rise of Israel) (““)"2017).

Israel arrested Senwar in 1988 for "Resistance activities" and sentenced him to life imprisonment. He was released in October 2011 as part of an agreement to release thousands of Palestinian prisoners in return for an Israeli soldier, Gilad Shalit, who was held by Hamas for five years in the Gaza Strip (france24, 2017). Yahya al-Sunwar is considered a wing of the hawks inside Hamas and a close associate of the Izz al-Din al-Qassam Brigades, the military wing of Hamas. Political analyst Muhaimer Abu Saada in the Gaza Strip says that the choosing of Senwar has become an indication

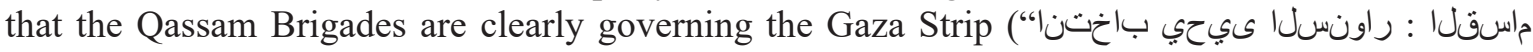
. 2017). سامح علع رطيست

Yahya al-Sunwar is considered as a leading figure and military high-level within the Hamas movement. Yahya al-Senawar and his brothers in the political bureau of Hamas in the Gaza Strip are trying to find appropriate solutions to cope with the difficult living conditions within the Gaza Strip and this requires flexibility in dealing with internal and external variables while maintaining The principles of the Hamas National Movement, an example of the files to be dealt with are the reconciliation file between the Palestinian Authority and Hamas, the file dealing with the Israeli enemy, the file dealing with Egypt and the countries supporting Hamas, including the Islamic Republic of Iran.

Secondly, there was Ismail Haniyeh that was elected as head of the political bureau of the Islamic Resistance Movement (Hamas), replacing Khaled Meshaal. Shortly after the release of Hamas's new document, Ismail Haniyeh, a resident of the Gaza Strip, was elected head of the Hamas political bureau in place of Khaled Meshaal, a resident of Qatar, as a result of internal elections held by Hamas on the local, regional and international levels. Against other candidates Musa Abu Marzouk and Mohammed Nazzal, Khaled Meshaal announced the victory of Ismail Haniyeh as new head of Hamas (““)" 2017).

Al-Sharq newspaper (Qatari newspaper) described Haniyeh's election as a democratic wedding and a unique experience. The newspaper pointed out in its editorial that Haniyeh's election, a week after Hamas issued its new document, confirms the movement's keenness to gradually change its positions aimed at abandoning isolation and turning to entering the game of international negotiations without compromising historical rights or waiving the national constants of the issue (ثيمالعإلإن, 2017).

Ismail Haniyeh is considered a flexible figure within Hamas, where the Financial Times said that the choice of Ismail Haniyeh is considered a balancing act of Hamas' internal forces, which comes after the election of Yahya al-Sunwar, a militant within Hamas. Some analysts believe that the election of Ismail Haniyeh would Paving the way for the movement to enter the PLO and to open up to the

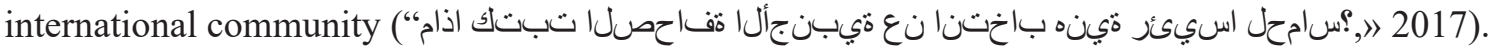

The election of Yahya al-Senawar and Ismail Haniyeh was an important part of the political development of Hamas, that the decisions taken within Hamas are collective decisions and not individual. The change of leader of Hamas' in Gaza or at the political level will not affect much. On the general policy of the movement which operates according to the framework institutional and collective according to the principle of Islamic consultation (Shura principle). 


\section{The differences between the 2017 Hamas document and the 1988 Hamas charter}

The charter of the Islamic Resistance Movement Hamas, issued in 1988, contains the following points:

The first point is the battle on the land of Palestine is a battle between Jews and Muslims and that the conflict is purely religious and that the occupation of the Jews should be eliminated from the land of Palestine. Article 15 of the Charter states that in the face of the rape of the Jews of Palestine, Islamic community among the masses locally, Arab and Islamic, and must be broadcast the spirit of jihad in the nation and the fight of enemies and join the ranks of the Mujahideen ("مواقحل قاكرح قاثيم" . 2017). (1988) سامح ةيمالسإل

The second point is the terms of accession to the Palestine Liberation Organization, where the Charter spoke about the PLO and its secular thinking of the Palestinian state. Dealing with the Palestine Liberation Organization should be based on participation in building the Palestinian state in an Islamic rather than a secular way. Article 27 of the Charter stipulates that the PLO adopted the idea of the state Secularism. The secular idea is contrary to the religious idea, and the ideas adopt positions and actions, and take decisions.

The third point is the land of Palestine is the land of Islamic cessation according to the Charter of the Hamas Movement, where Article XI stated that the Islamic Resistance Movement believes that the land of Palestine is the land of Islamic rules and for the generations of Muslims until the Day of Judgment, and no one has the right to waive it, whether he is a king or a president or an Arab organization. Or international, as the land of Palestine is the property of the Islamic generations.

The fourth point is the charter considered the Islamic Resistance Movement Hamas is an integral part of the Muslim Brotherhood. Furthermore, Hamas is the Palestinian part of the mother movement, the Muslim Brotherhood, where the text of the Charter in the second article that the Islamic Resistance Movement wing of the Muslim Brotherhood in Palestine. The Muslim Brotherhood is a global organization, the largest Islamic movement in modern times (ب. بو جرلا . 2010).

In 2017, with the political and intellectual development of Hamas and with the regional changes, it was necessary to work on developing the charter of the movement in line with the requirements of the modern era but does not affect the Palestinian constants. Hence, a new document was issued by the Islamic Resistance Movement Hamas expressing the political vision towards several issues and files, where the most important points of the document are as follows:

First, the conflict on the land of Palestine is a political conflict, not a religious one. The new document states in Article 16 that the conflict with the Zionist project is not a conflict with the Jews because of their religion. Hamas is not fighting against the Jews because they are Jews, but is engaged in a struggle against the occupying Zionist aggressors.

Second, The Palestine Liberation Organization (PLO) is a national framework for the Palestinian people at home and abroad. Article 29 states that the PLO is a national framework for the Palestinian people at home and abroad. It must be maintained and it must be developed and reconstructed on a democratic basis in order to preserve Palestinian rights.

Third, the document did not mention an wakf of the land of Palestine (mortmain property, is an inalienable charitable endowment under Islamic law), but stressed the historical right to Palestine, where included the following text in Article XX: "No waiver of any part of the land of Palestine, whatever the reasons and circumstances and pressures, no matter how long the occupation, Hamas rejects any alternative to the complete liberation of Palestine, it blamed her boiling sea."

If the establishment of full sovereignty of an independent Palestinian state and Jerusalem as its capital, on the fourth of June 1967 lines, with refugees and displaced persons return to their homes that come out of them, is a compromise formula and a national common, it does not mean at all 
recognition of the Zionist entity, as It does not mean to waive any right penny Linnaean. "Which supports the Palestinian consensus based on the 2006 National Accord document ("Hamas", 2017).

Fourth, the document did not mention anything about the Muslim Brotherhood, but defined Hamas itself in the first article as a liberation movement and an Islamic Palestinian national resistance, aimed at liberating Palestine and confronting the Zionist project. Its reference comes from Islam and its principles, objectives and means (برل, 2017).

The new document of the Islamic Resistance Movement (Hamas) expresses the extent of political and intellectual development in its dealings at all levels, whether the movement's internal affairs or dealing with Palestinian parties or movements or at the regional level regarding dealing with regional countries. This development is qualitative progress at the level the new document of Hamas proves that the movement is capable of flexibility and dealing with the demands of the times, a movement in its Islamic origins.

Some writers and researchers see a clear contradiction between the Hamas movement in its new document stating that there is no waiver of the historic land of Palestine and that the land of Palestine is the property of the Palestinian people. In the same document it stipulated that the establishment of a Palestinian state on the 1967 borders is a common ground between Hamas and other Palestinian parts such as the Palestinian authority.

The discourse adopted in the Hamas Charter of 1988 was a religious speech par excellence that addresses Muslims all over the world. It stems from religious beliefs based on the Qur'an and the Sunna. In other words, it is an internal charter of the movement and its members. They have the same logic in thinking, style and dealing. From 2006 to 2017, the presence of Hamas has become not only in the local level but also developed at the regional and international level.

Hamas should have developed its modern thinking and rhetoric to be compatible with the regional and international situation, by consensus of the internal councils of Hamas. The new Hamas is not only addressed to one party, but to the regional and international community, hence the idea of considering the establishment of a Palestinian state on the borders of the 67 as a way to achieve the highest goal, a historic liberation of Palestine.

In order to complete the picture on the new Hamas document, we must look at the local, Arab, regional and international positions on this document. The Islamic Jihad Movement in Palestine had a position on this document, as well as others inside the Palestinian, Arab countries, headed by Egypt and Saudi Arabia. In Iran, who is confident of the new Hamas and the nature of the impact after the announcement of the document on the relationship between Hamas and the Islamic Republic of Iran, the position of a number of European countries, the position of the United States of America and its opinion in the document?

\section{Local attitudes of the new Hamas document 2017}

\section{The Palestinian Authority's position on the new Hamas document}

Palestinian President Mahmoud Abbas said that "the new Hamas document bears many contradictions and that a peaceful solution is the only way to end the Palestinian-Israeli conflict." He added: "We and the world have no other choice but a peaceful solution. There are no other options and about the military option. It is not an option for us dealing with Israel's, it was long time ago and finished.

When we talk about a peaceful solution, we find that the whole United Nations, all the countries of the world with us, the great powers are all with us, Europe with us, the majority of the Israeli people with us, and this is important (Alouf, 2017; “" 2017). 
President Mahmoud Abbas (Abu Mazen) is one of the most important figures who contributed to the peace agreement between the Palestinians and the Israelis in 1991, known as the Oslo agreements, and President Abu Mazen has often rejected the use of the armed struggle against the State of Israel. He supports the idea of peaceful resistance, and the boycott of Israeli goods (O'Loughlin, 2004).

President Mahmoud Abbas believes that the only strategic option for reaching a final solution with Israel is the negotiations and that the pressure on Israel is through peaceful popular resistance until Israel acquiesces to the demands of the Palestinian people (بو جرلال ع 2014). Author believes that the option of peace has been put forward since 1991 until now, so where is the Palestinian state on the ground? The Islamic resistance in the Gaza Strip forced the Israeli enemy to leave the Gaza Strip with armed resistance. Peaceful resistance with the occupation is inevitable, but according to international laws and norms, resisting the occupier of all types of resistance, including armed resistance, is normal.

\section{The position of the Islamic Jihad Movement in Palestine from the new Hamas document}

The Palestinian Islamic Jihad (PIJ) announced its reservations on the principles and policies of the Islamic Resistance Movement (Hamas), saying that "acceptance" of the establishment of a Palestinian state on the 1967 borders "violates the principles."

Ziad Nakhla, deputy secretary-general of the Islamic Jihad movement, said that what was mentioned in the document on the Palestinian state "is re-producing the maze that we have introduced in the PLO's interim program."

"The Jihad movement rejects this solution," he said, adding that the wording "affects the sentiments of the comrades in arms". "We as partners of the Hamas brothers in the resistance and liberation project, wished that we would congratulate them on this important document, but frankly, out of favor, we are not comfortable with some of what has been said."

"In terms of the political situation, the document is evolving and progressing," he said. "But on the impasse, the search for solutions and half solutions to the Palestinian issue under the umbrella of socalled international legitimacy."

Ibrahim Hamami, a Palestinian political analyst, said that the Palestinian parties including the Islamic jihad have the right to be concerned about the new Hamas document, but this comes through constructive criticism and from the brotherhood and advice. He called on the Palestinian partied to give the document an opportunity to see the light and that the time will prove whether Hamas recognized Israel or that the new document in the interest of the Palestinian people (2017).

The researcher agrees with Ibrahim Hamami, where most political experts accuse the Hamas movement of intentions and personal illusions and not for real actions, and this is not logical, Mohammed Tamimi Islamic researcher accused Hamas in several points.

The Hamas movement in its new political document did not speak clearly about the Arab and Islamic dimension of the Palestinian issue, but focused on the Palestinian issue and that the Palestinians alone have the right to make a decision on the Palestinian issue (10ز 2017) and this is not true because the new document clearly stated in Article VII that Palestine in the site The heart of the Arab and Islamic nation.

That there is a clear contradiction between the position of Hamas in the liberation of the entire Palestinian territories and the acceptance of the establishment of a Palestinian state on the borders of the 67, where he raised an important question, which is the way to establish a Palestinian state on the borders of 67, Is it the path of negotiations or weapons? The answer is clear: this document talks about the general principles and policies of Hamas and not about the mechanisms that Hamas will follow. As for the mechanisms, there are many examples in which Israel withdrew unilaterally 
without negotiations or agreements. This happened in southern Lebanon and the Gaza Strip Where Israel has withdrawn unilaterally without engaging in prior negotiations.

Plus this option about having Palestinian state on the 67 borders, come under the Palestinian Consensus and approve on this common point between all the Palestinian people, especially between Hamas and Fatah movement.

\section{The position of the Palestinian National Liberation Movement (Fatah) from the new Hamas document}

Fatah movement said the new Hamas document was identical to that of the PLO in 1988. Fatah demanded Hamas to apologize to the PLO after 30 years of betrayal and atonement, which caused a sharp split in the Palestinian street.

Fatah spokesman Osama al-Qawasmi said: "Hamas's acceptance of the establishment of a Palestinian state within the framework of June 4, 1967 as a compromise formula and the implementation of international law is exactly the situation in which all the factions came out in 1988. This was not a position of Fatah, it was the position of all Palestinian parties back then (ي), 2017).

\section{Regional positions of the new Hamas document}

\section{The Turkish and Qatari position on the new Hamas document}

The position of Qatar, which hosts Hamas' political leadership and provides it with much political and financial support, can be further strengthened and the document will provide Qatar with a good cover to defend Hamas in various forums (لاعلادبع, 2017).

Turkey, whose president Recep Tayyip Erdoğan welcomed the document, also has good relations with Hamas and wants to change the prevailing image of Hamas by integrating it into the political process through a more moderate political approach (طسو ألا), 2017). It is concerned not to isolate Hamas and restrict it but to present it to the world as a party. Important role can play a role in achieving security and stability in the region. Turkish Foreign Minister Mouloud Javishoglu congratulated Ismail Haniya on his victory in the Hamas political bureau and praised the "democratic state of Hamas" as well as the issuance of the political document.

The Turkish Foreign Minister had said earlier that "everyone knows the difference between the Hamas political line past and current," saying "Turkey is one of the most countries that contributed to make this difference" (4), 2017).

\section{The position of the Islamic Republic of Iran and Lebanese Hezbollah from the new Hamas document}

Iran has not issued an official position on the document, but the document was attacked by Iranian media and writers and activists close to the Iranian regime. The group dissatisfaction with Hamas stems from its positions on regional issues, foremost of which is Hamas' position on the Syrian regime. The other group motives are concerned about the future of Hamas, "The Resistance Project" and a third group exploited the issue to settle internal accounts that have nothing to do with Palestine or Hamas (يربنع, 2017).

Hezbollah, however, has expressed its position, Deputy Secretary-General, saying: "The party is not with the resistance that paves the way for the settlement, nor is it with the resistance that divides Palestine into two states or the resistance that exchanged blood with the land." The party is with the resistance, the land is full without restrictions or conditions. 
A breakthrough in the relationship between Hamas on the one hand and Iran and Hezbollah on the other is also linked to developments in the region and the positions of Hamas and its new leadership towards them. In any case, the document will not be a barrier to the development of Hamas' relations

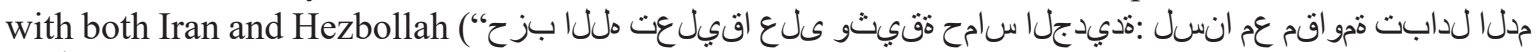
. 2017).

The researcher said that Hezbollah and Hamas have many common points, including the Israeli enemy, but how to deal with this enemy is due to the literature of every movement, depending on their circumstances, strengths and weaknesses.

\section{The Egyptian, Saudi and Jordanian positions on Hamas' new document}

As for the Egyptian position on the new Hamas document, it was stated by many Egyptian observers and researchers. Abdalnaser Salamh said that the new Hamas document is a natural political development for the difficulties faced by Hamas on the regional and international levels. Hamas's statement in the document when it stipulated not to accept the establishment of an alternative Palestinian homeland, in reference to the Sinai or any place other than the Palestinian territory (2017), 2017).

Ambassador Mohamed Al-Orabi, former Egyptian foreign minister stated that the movement appears to be aimed at improving relations with the Gulf States and Egypt, which view the Muslim Brotherhood as a threat to the security and stability of the region. The separation of Hamas from the Muslim Brotherhood - according to Orabi - a "positive step" to melt the relationship with Egypt, having become "hot tin" since the Muslim Brotherhood banned and considered a "terrorist group" after the overthrow of former President Mohamed Morsi in 2013 (1), 2017).

As for the position of Saudi Arabia and Jordan on the new Hamas document, no official statement was issued by these countries. Their main problem with Hamas is their actual connection with the Muslim Brotherhood and behavior on the ground, including the position on the Arab peace initiative.

Jordanian writer Issa al-Shuaibi in the Jordanian newspaper Al-Ghad expressed optimism about the upcoming summit between Abbas and Trump. He said of the new Hamas document: "It gives rise to some hope in bringing the issue back to the international agenda. This new document could be a reliable anchor for Mahmoud Abbas in his negotiations with the American and Israeli sides" (ث) 2017).

\section{International positions on the new Hamas document}

\section{The European position on the new Hamas document}

The European Union considered that the issuance of the document of principles and policies by Hamas would not change their attitude towards Palestine (ققيثو ابوروأو نطنشاو تلبقتسا فيك" (2017).

But a spokesman for the European Union, in a statement to the Italian news agency Aki, did not hide the EU's satisfaction with the publication of the document. "It provides a welcome and renewed opportunity for the Palestinian factions to participate in a comprehensive reconciliation process," he said. He urged all Palestinian parties to take this opportunity.

"The change in Hamas' position helps us to lift the siege imposed on the Gaza Strip since 2007, which has led to a catastrophic situation on the population, and we must end this siege," said the head of the European parliamentary relations committee with Palestine, Nicolez Silikotissan. The European Parliament added that "the document of principles and policies" is an "important transformation", and we hope that this will help to achieve national unity among the Palestinians on the one hand, and to reach the desired two-state solution on the other hand (يلكصلال,2017). 


\section{The US and Israeli position on the new Hamas document}

The United States has confirmed that its position has not changed from Hamas after the issuance of its new political document. According to a source in the US State Department, Hamas is still a "terrorist organization" and it is included in the list of international terrorism - according to the Anatolia Agency. The State Department has classified Hamas since 1997 as a terrorist organization

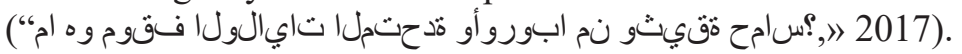

The American Wall Street Journal has published a report entitled "Hamas renounces the call to destroy Israel" and cited most of the points of the document that were interested in other newspapers, explaining that this public abandonment attempt to change its image at a time when US President Donald Trump to revive the peace efforts in the East Middle East (Jones 2017).

The United States has confirmed that members of the Quartet, which is composed of the United States, Russia, the European Union and the United Nations, will not engage in any dialogue with Hamas until it accepts its three conditions: "renouncing terrorism" and "recognizing Israel" And “acceptance of agreements signed between Israel and the PLO" (لاعلادبع, 2017).

Although Russia has good relations with Hamas. Russia is trying to influence all the Middle East issues, especially the Palestinian issue. It has relations with most of the parties involved in the Palestinian cause, including Hamas and the Gaza Strip (تينيطسلف لئاصف فيضتست ايسور)"2017). .

The Israeli position is always on the side of hostility against Hamas. Israel has rejected the new document in full. Israeli Prime Minister Benjamin Netanyahu has denounced the document as negative. He ripped it apart and said it did not concern the Israeli people ("Netanyahu throws new Hamas paper policy into trash," 2017).

\section{The Russian position on the new Hamas document}

The Russian Foreign Ministry pointed out that a number of the guidelines contained in the new Hamas political document, including the acceptance of a Palestinian state within the 1967 borders, represent

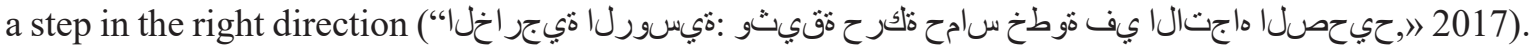

"We are determined that the task of achieving national unity will require Hamas and other Palestinian factions to take further steps, and Russia is determined to continue its support for the Palestinians on this issue," the Russian Foreign Ministry said in a statement.

The Foreign Ministry stressed that Russia consistently supports the restoration of national unity on the basis of the political "Fatah" program and the Arab peace initiative, stressing that "overcoming internal Palestinian differences will create the conditions necessary for a just solution to the Palestinian

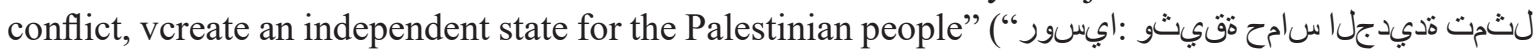
2017). حي حصلا هاجتالا يف موطخ ل.

"In this context, Moscow received with interest the changes that took place in Hamas, the election of Ismail Haniyeh as head of the political bureau of Hamas, and the announcement of the new political document after long discussions (")" 2017).

\section{Conclusion}

There are fundamental changes in the new Hamas document. It redefined Hamas as a national liberation movement prepared to gradually resolve the June 4, 1967 borders, and to open up both the Palestinian and the world in political language and a different discourse. The document will not make a major breakthrough in Hamas 'relations with local, regional and international parties at least for the time being. However, the document could help Hamas in its political future open up better channels 
of dialogue with the actors in the Palestinian cause, but this depends mainly on Hamas' ability to Marketing this document and convincing the parties that there has been a fundamental change that has taken place and that there is something to build on.

Hamas has never been a problem in its literature or documents. It has always been the problem of carrying arms, pursuing armed resistance, and its unbalanced relationship with the Islamic Republic of Iran. The Iranian side regards Hamas as an Iranian card in the Middle East.

In the final outcome of the new in the political thought of Hamas can be the most important results: the shift towards the Palestinian national political thought of the PLO before the amendment at the expense of Islamic political thought derived from the thinking of the Muslim Brotherhood. Yes, there is a change in the program of the Islamic Resistance Movement, there is progress and retreat, and there is an attempt to marry between Islamic religious ideology and political pragmatism. Yes, the liberalism of the new Hamas document is a milestone in Palestinian history, the time will prove for us about Hamas new document if it's on the right or wrong way.

\section{References}

“Hamas", T. I. R. M. (2017). A Document of General Principles and Policies. Retrieved May 20th, 2017

Alouf, J. M. a. R. A. (2017). New Hamas charter acknowledges 1967 borders ahead of Abbas US visit. Retrieved June 5th, 2017

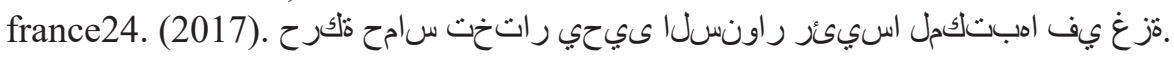

Jones, R. (2017). Hamas Drops Call for Israel's Destruction. Retrieved June 10th, 2017

. Netanyahu throws new Hamas paper policy into trash. (2017). In P. N. Videos (Producer). https:// www.youtube.com/watch? $\mathrm{v}=\mathrm{MwVkpt} 4 \mathrm{bPAE}$.

O’Loughlin, E. (2004). Abbas calls for end to armed struggle. Retrieved May 5th, 2017

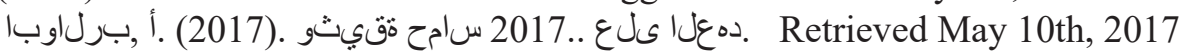

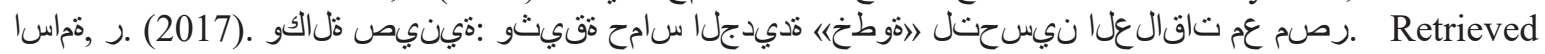
June 7th, 2017

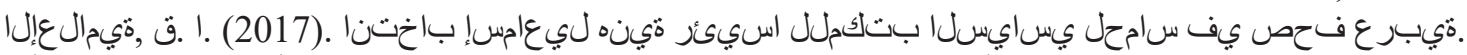

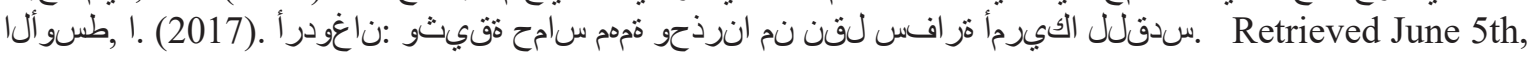
2017

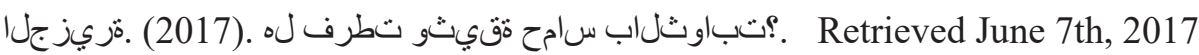

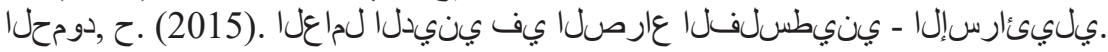

. 2017. Retrieved June 6th, 2017

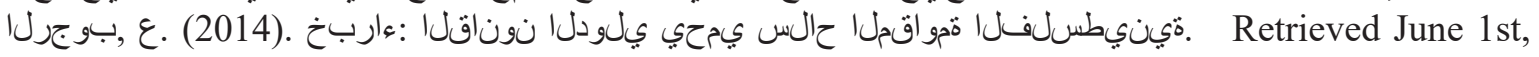
2017

ف Retrieved March 14th, 2017

2017.

. ح , ريلكصلا . (2017). Retrieved June 10th, 2017

قديدجل سامح مقيثو شقانت قيبر ع فحص . Retrieved June 6th, 2017

88. Retrieved June 9th, 2017

2017.

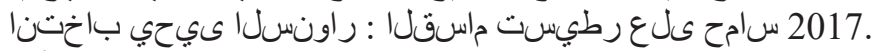

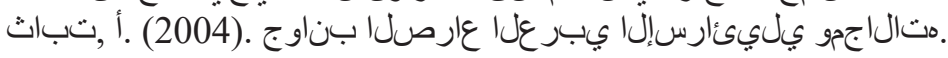

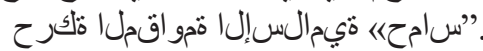

2007.

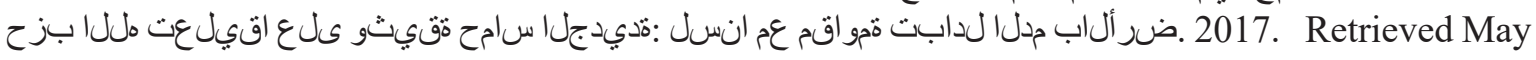

29th, 2017

2017. Retrieved May 4th, 2017 
ايسور. 2017. Retrieved June 5th, 2017 سامح ثقيثو . Retrieved May 16th, 2017

. بامش . 2017). Retrieved May 25th, 2017

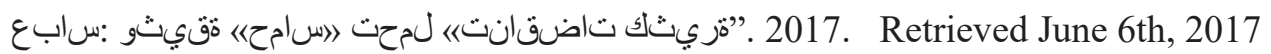

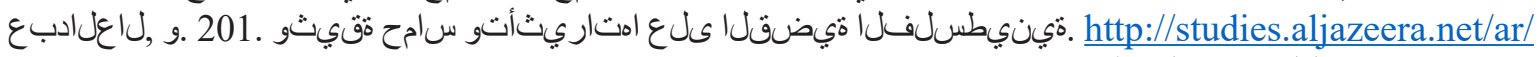

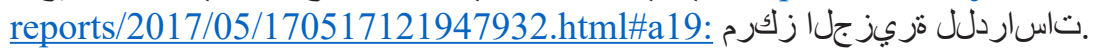

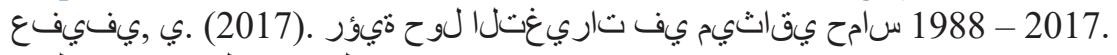

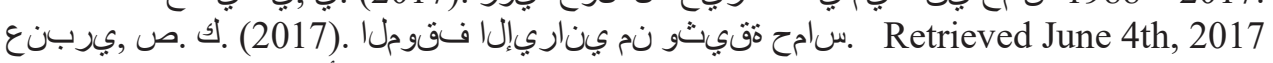

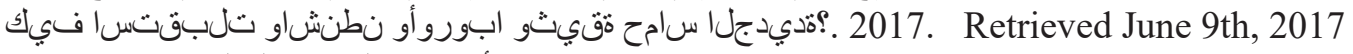

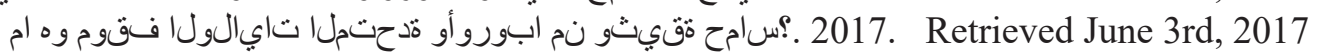
2017.

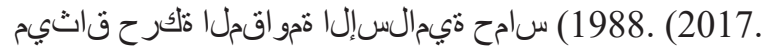
2017. 2004 .تافر عرساي. 